\title{
Effect of Hand-Eye Coordination, Concentration and Believe in the Accuracy of Shooting in Petanque
}

\author{
Ari Purnomo*, Yendrizal \\ Sports Coaching Education Program \\ Faculty of Sport Science \\ Padang State University, Padang, Indonesia \\ purnomo_ari95@yahoo.com
}

\begin{abstract}
The problem in this study is that Jambi Provincial Petanque athletes still lack shooting accuracy in Petanque matches. This type of research is quantitative research with a path analysis approach involving 40 athletes. The purpose of this study is to determine the direct and indirect effects on shooting accuracy. Data were collected with a tennis ball throwing test to the wall to measure hand-eye coordination and concentration exercise to measure concentration, a questionnaire to measure confidence, and a shooting accuracy test. The results showed that 1). The effect of hand-eye coordination variables on direct shooting skills is $\mathbf{1 0 . 4 9 \%}$. 2) Concentration has a direct effect of $23.32 \%$. 3). Confidence has a direct effect of $19.53 \%$. 4). Hand-eye coordination through Trust in Shooting Accuracy is $\mathbf{7 4 . 1 3 \%}$ 5). While concentration through confidence in shooting accuracy of $5.4 \%$. Conclusions thus, there are direct and indirect effects of hand-eye coordination, concentration, and self-confidence in the accuracy of shooting in Jambi Province petanque athletes.
\end{abstract}

Keywords-Hand-Eye Coordination, Concentration, Confidence and Shooting

\section{INTRODUCTION}

"Sports education is physical education and sports are carried out as part of an organized and continuing education process to obtain knowledge, personality, skills, health, and physical fitness" [1]. Physical education as one of the subsystems of education that must be taught in schools has an important role that is very central in the formation of Indonesian people as a whole. Physical education also has a role to stimulate involvement in sports and physical activities, laying the foundation for a healthy life throughout life and involvement in social life.

In carrying out human sports have different goals, this is because each human being to do sports in accordance with the goals he wants. "That there are four basic objectives for people to do sports activities according to among others (1) They do sports activities for recreation, (2) Those who do sports activities for educational purposes, (3) They do sports activities with the goal of achieving a level of physical fitness, (4) They carry out sports activities to achieve achievement as

the final goal. To achieve these objectives requires effort through directed planning and implementation" [2].

Sport has also become a necessity for every

human being, because people are increasingly aware that exercise is very useful to improve fitness, freshness, and health. and also by doing sports activities to increase work productivity. Thus many people use their place and free time to do sports activities and some even do sports with programs that have been made by their instructors.

One type of new sport that is gaining popularity in Indonesia is the Petanque sport. Although classified as a new sport in Indonesia, Petanque is actually a sport that already has a name in the world, countries that are strong and consistently develop petanque are countries that were colonized by France, the country that gave birth to the sport. Pétanque is a form of playing boules whose aim is to throw an iron ball as close as possible to a wooden ball called a cochonnet (jake) and the foot must be in a small circle. This game is usually played on hard ground or oil, but can also be played on grass, sand or other soil surfaces. In Indonesia, petanque sports entered the 2011 Sea Games event in Palembang. Koni, South Sumatra

Province immediately appointed PDPDE (Regional Company of South Sumatra Province) to form the organization for Petanque. Further development after SEA GAMES XXVI2011 and to deal with national and international multievent activities, FOPI was appointed by KONI to immediately build FOPI structures and develop this sport throughout Indonesia. Jambi Province is one of the places to develop petanque sports which has now 
been running for approximately 3 years. Jambi Province petanque club has now grown with the events held and events that are participated in the National and International scope. In the National and International events the branch of Petanque sports competes 11 categories, namely shooting men, shooting women, single men, single women, double men, double women, double mix, triple men, triple women, triple $2 \mathrm{w} 1 \mathrm{~m}$, triple $2 \mathrm{~m} 1 \mathrm{w}$. Jambi provincial petanque club athletes have participated in many championships and received many awards and experiences.

Within the scope of the Jambi Province petanque club has begun to be respected when participating in various championships. Evidenced in the acquisition of awards at the championships at the National level, the Jambi Province petanque club has gained many achievements among its 19th ASEAN UNIVERSITY GAMES IN Myanmar, National Championship 3 Petanque Cup Rector of Surabaya State University, 3rd National Championship, UNSYIAH Aceh Petanque Branch with 5 Gold 1 Silver 1 Bronze as overall champion, International marathon champions 2018, National Championship for the second Indonesian FOPI Anniversary, $\mathrm{xv}$ national student sports week (pomnas) in Makassar, 29th Sea Games in Kuala Lumpur, 2016 West Java PON Exhibition.

From the data above and the results of the researchers' observations it appears that the Jambi provincial petanque club has gained many achievements in the national scope. But when Jambi petanque club athletes took part in international championships, Jambi provincial athletes were still unable to compete with athletes from outside clubs. Direct observations on the 29th sea games of Kuala Lumpur in 2017 and the 19th ASEAN UNIVERSITY GAMES In Myanmar in 2018 the Jambi athlete's point score in the shooting number was just under 30 points, whereas the full score was 100 points (FOPI, 2015) . This shows that these results do not meet the $50 \%$ point of the full point. Not getting points and medal, means the lack of accuracy of shooting conducted on the intended target. To achieve achievement there are 4 components that play an important role, namely, 1. Biological aspects include the potential or basic abilities of the body, the functions of body organs, nutritional posture. 2. The psychological aspects include intellectual, motivation, personality, motion coordination, and self confidence. 3. Environmental aspects include social, facilities and infrastructure, weather or climate. 4. Supporting aspects include trainers, training programs, awards / bonuses.

In shooting, there are components that influence shooting, namely, grip of the ball, body position toward the target, static balance of legs, low body position and leaning forward, relase the ball, follow through. Researchers saw when in the game, Jambi Province petanque club athletes apparently still made a lot of mistakes in shooting, one of which is in the coordination between the eye and the hand holding the ball. Where the coordination of the hands is supported by the strength of leg muscles used to support the organs of the upper body and hold additional movements during swing shooting. In addition to eye coordination and concentration and confidence, it is also used to regulate the alignment of the ball when shooting.

Because when shooting athletes must consider distance, power, throw angle, and straight. There are 2 types of pitches in petanque sports namely pointing and shooting. Pointing is a type of throw to approach the target boka closer than the opponent's bosi. Basic Pointing Techniques: Rolls throw bosi less than 3 meters from the circle where the bosi is rolling along the arena near the target boka. Soft Lob / Half Lob throws the bosi a little higher to form a curve and the bosi falls and rolls into the target boka. High Lob / Full Lob throws the higher bosi almost vertically and the bosi falls and rolls onto the target boka. Shooting is a type of throw to repel opponent's bosi from the target boka.

In addition to eye hand coordination, concentration, and confidence in the use of training models is very helpful in the process of training activities, especially helping improve athlete's skills. however, in its implementation there are not many trainers who can create variations of the exercises so that the exercises are not yet effective and efficient. especially in basic shooting techniques there are still many errors of movement starting from the start, implementation, and follow-up movements. this causes the results of the shooting shot to be very far from the target, even though shooting is one of the training materials in petanque sports, where the shooting practice itself consists of several simultaneous and continuous movements that are carried out to distance and shoot bosi. Based on these problems the researchers wanted to see the effect given by hand eye coordination, concentration, and confidence in the accuracy of shooting in Petanque sports.

\section{Petanque Sports}

These petanque sports characters tend to play games that require accuracy in playing. Petanque sports do not require physical conditions like other sports, so this sport can be played by children, adults, the elderly and even the disabled. Petanque sport also does not require a special field, this sport can be played anywhere and by anyone, so that this sport can also be used as an alternative choice in the sport of recreation and health.

Petanque is a form of playing boules whose aim is to throw an iron ball as close as possible to a wooden ball called a cochonnet and the feet must be in a small circle. "Petanque is a sports achievement, the original form of this game appeared in 1907 at La Ciotat, in Provence, in the south of France" [3]. The name comes from Les 
PedTanco in the provencal dialect in Occitan which means tight feet. McNeely "Petanque is a sport that requires manipulative skills (throwing) and visualobject control where the players must toss the boules to land close to the jack for points" which means. "Petanque is a sport that requires manipulative skills (throwing) and visual object control where athletes must throw boules to land close to the jack to get points" [4].

\section{Hand Eye Coordination}

The ability of coordination is the basis of motion and basic motion in learning various sports skills, especially for sports games and sports that use equipment during a match or race. "Every person to be able to perform movements or skills both from the easy, simple to the complicated set and governed from the central nervous system that has been stored in memory first" [5].

Coordination is needed in almost all branches of sports and games, coordination is also important when in an unfamiliar environment, such as changes in the playing field, equipment, weather, lighting and opponents encountered. Good level and whether or not the coordination of one's movements is reflected in the ability to make a movement smoothly, precisely, quickly and efficiently. As where Bompa's opinion is that the higher the level of coordination, the easier it is for people to learn new and complicated techniques and tactics. "An athlete with good coordination is not only able to perform a skill perfectly, but also easy and fast in doing skills that are still new to him" [6]

Good coordination can change and move quickly from one pattern of motion to another so that the movement becomes effective Coordination involves the role of the eyes, hands and feet that are moved together. Coordination is an integrated movement between hands, eyes and feet at the same time" [7]. Athletes with good coordination between eyes and hands will produce a

precise and careful movement. The level of coordination or good or bad coordination of one's movements is reflected in his ability to make a movement smoothly, precisely and efficiently. An athlete with good coordination will be able to perform skills perfectly as well as easily and quickly in doing skills that are still new. Athletes can also easily move or change their movement patterns from one motion pattern to another so that their motion becomes efficient. Skills that use the element of coordination involve concentration (footeye coordination) or eye-hand coordination (eye-hand coordination) as well as eye-foot and hand coordination.

Basically coordination is the ability to overcome harmony in the movement of body parts, the ability to develop with body control. This statement is clear that individuals who are well coordinated will be able to control their movements according to their abilities. "Thus to achieve the goal of good coordination, it is necessary to have exercises that can develop coordination skills, a good exercise to improve coordination is to do a variety of movements and skills" [8].

The hallmark of hand-eye coordination is to produce accuracy with full accuracy effectively and efficiently, with a high degree of accuracy describing good hand-eye coordination. "The accuracy and accuracy of the movement can only be done if the athlete has good coordination. Athletes with good coordination reflect high technical skills" [9]. "The basic characteristic of high quality technical skills is the accuracy and accuracy of the movement and / or the results of the movement" [10]. With accuracy and movement will produce movement efficiency. Coordination involves the role of the eyes, hands and feet that are moved together. Athletes with good coordination between eyes and hands will produce a precise and careful movement.

Hand eye coordination is defined as a harmonious relationship of the interplay of muscle groups during work, "which is indicated by various skill levels" [11]. Coordination is as a whole of the pattern of movement of a group of muscles at the time of performing the movements which ultimately results in a person's skill level. "When making a throw with the ball, the eye will see the situation and digested in the form of a stimulus that will move the muscles, especially the hands when throwing the ball" [12]. Coordination is also a combination of muscle, bone and joint contractions in displaying a movement, so that the coordination ability is closely related to other motor skills such as balance, speed, accuracy, and eye hand coordination.

"Without having good motion coordination skills, individuals will have difficulty learning basic technical skills" [13]. It was also further stated that in the coordination of eye and hand movements will produce timings and accuracy. The higher the level of coordination, the easier it is for people to learn new and complicated techniques and tactics. Basically coordination is the ability to overcome the harmony of motion of body parts, the ability to develop with body control. This statement is clear that individuals who are well coordinated will be able to control their movements according to their abilities. Coordination is also an integral part of motor skills, in fact the notion of coordination has been considered as an equivalent of the word motor skills and skills.

Based on the description above, therefore eye hand coordination is the ability possessed by a person to combine eye sight with a target with the accuracy of the hand in throwing so that there is a 
movement that is consistent with what is desired by the person, namely accuracy and accuracy.

\section{Concentration}

"The inability of athletes to concentrate can be caused by disruptive stimuli originating from outside and within the athlete" [14]. Disturbing stimuli from external athletes are also called external stimuli. Examples of external stimuli that can interfere with athlete concentration are competitors or other athletes, coaches, competition committees, spectators, and where the competition is held. Meanwhile, "the concentration disturbing stimulus originating from within the athlete is called an internal stimulus" [15].

External stimuli that interfere with concentration in the statement, such as audience cheers, loud music, hurtful words both from the audience and from the coach, and unsportsmanlike actions from the opponent. While internal stimuli such as feelings of body disruption and other feelings that are felt disturbing physical and psychological state, for example I am really tired, I'm nervous and so on. Exsternal and internal stimulants are two separate categories, but they can continuously affect the attention and concentration of athletes.

Concentration is one's ability to focus attention on the selected excitement (one object) in a certain time. That is, the process of concentration is always preceded by a person's attention to a selected object. Thus concentration is a concern in a long time span, so that during sports activities required is concentration. Fatigue is also one of the problem factors in attention. "Concentration can be easily lost due to fatigue, therefore the condition of the body is very important" [16].

In essence, fatigue can reduce little by little the process of focusing attention on the situation. Individuals who have less motivation will certainly be difficult to concentrate. Without good concentration, athletes can make various mistakes in performance such as failure to display the techniques that have been learned, inaccurate sports movements that should be done. In principle, an unrelated one will facilitate interference if one is out of focus. Following the flow / process of concentration.

\section{Confidence}

That self-confidence is important for achievement. "Low self-esteem can potentially lead to low achievement. This is because that low self-esteem can cause individuals to not be able to deal with complex problems" [17].

Confidence is one aspect of personality that is the basic capital and is formed through a process of training

and interaction with the social environment". The lack of confidence in an athlete is an obstacle to high achievers, when experiencing failure the athlete will already feel inadequate or lack confidence in his abilities, so it is easy to despair and if demanded to perform even higher will easy to experience frustration [17]

\section{RESEARCH METHODOLOGY}

This type of research is a quantitative study with a causal associative correlation approach, the purpose of this study is to determine the direct effect of hand eye coordination, concentration, and self-confidence on the accuracy of shooting shooting in Jambi Province. This research belongs to the type of quantitative research that uses simple regression data analysis techniques and multiple regression, after that it is followed by path analysis (Path Analysis).

This research was conducted in April May 2019, this research was located in the Jambi University petanque field. When the research is used to carry out activities include: preliminary research, making research proposals, seminar proposals, arranging research permits, testing instruments, testing the validity and reliability of the instrument, collecting data conducted as many as 3 meetings where the first meeting is to obtain data and coordinate data collection eye hand, the second meeting to take the data of the test of selfconfidence and concentration, the third meeting to take data on the accuracy of shooting petanque sports. In this study, the population was Petanque

athletes fostered by Jambi Province which consisted of 3 levels of active athletes, meaning superior athletes to prepare for the championship, passive athletes namely reserve or second tier athletes from active athletes, and reserve athletes, namely beginner athletes recruited from each each regency / city numbered 103 people with the following details. In this study sample withdrawal is done by purposive sampling technique, the intention is to determine the sample technique with certain considerations. Based on this, the samples in this study are athletes with active categories totaling 40 people, because in this group it is very appropriate to lay the foundation of the game petanque and in this category athletes who actively practice and participate in each match and athletes are familiar or not awkward again with the basic technique of petanque, so this research is more emphasized on the stabilization and smoothing motion of the basic technique of playing petanque itself.

To find out hand eye coordination, the hand eye coordination test was carried out by throwing a tennis ball at the wall that was given a target by Ismaryati (2006: 37). The concentration used the grid concentration exercise test. Based on previous studies, grid concentration exercise theoretically has reflected its compatibility with what has been measured. The instrument used to measure confidence in this study was a Likert Scale model questionnaire with five alternatives. For 
accuracy shooting instruments with petanque shooting tests.

\section{RESEARCH RESULT \\ Petanque Shooting Skills}

Based on research data on shooting skills (Y) the lowest score is 3, the highest score is 30 , so that the range is obtained 27. From the statistical calculations obtained an average value of 14.95 , standard deviation (s) of 6.41 and variance of 41,17 . From 40 research samples, the results of each respondent were compared with the average. It turned out that those who gained Shooting skills (Y) above the group average were 12 people (30\%), below the average group of 28 people ( $70 \%$ ).

\section{Hand Eye Coordination}

Based on research data on Hand Eye Coordination (X1) obtained the lowest score of 5, the highest score of 20 , so that the range is obtained 15. From statistical calculations obtained an average value of 12.1, standard deviation (s) of 3.81 and variance of 14.55 . From

40 people in the study sample, if the results of each respondent were compared with the average, it turns out that those who received Eye Hand coordination (X1) were above the average group of 13 people $(33 \%)$, below the average group of 27 people $(67 \%)$.

\section{Concentration}

Based on research data on Concentration (X2) obtained the lowest score of 3 , the highest score of 18 , so that the range is obtained 15 . From statistical calculations obtained an average value of 9, standard deviation (s) of 3.35 and variance of 11.28. From 40 research samples, if the results of each respondent were compared with the average, it turns out that those who get Concentration (X2) above the average group of 10 people $(25 \%)$, are below the average group of 30 people $(75 \%)$.

\section{Confidence}

Based on data from research on self-confidence

(X3) obtained the lowest score of 98, the highest score of 202, so that the range is obtained 104 From statistical

calculations obtained an average value of 155.25, standard deviation (s) of 35.22 and variance of 1241 11. From 40 people in the study sample, if the results of each respondent were compared with the average, it turns out that those who gained confidence (X3) above the average group were 20 people $(50.00 \%)$, below the average group of 20 people $(50.00 \%)$.

\section{Testing Data Analysis Requirements X1} normality test

Based on the calculation results of the liliefors normality test, the L0 price was 0.134 . Where the critical value of LO in the Liliefors table for sample size $(\mathrm{n})=40$ with $\mathrm{a}=0.05$ obtained a value of 0.14 . When compared to the calculated L0 value it turns out to be smaller than the L0 table, so it can be concluded that the X1 normality test has a normal effect.

\section{Normality Test X2}

Based on the calculation results of the liliefors normality test, the $\mathrm{L} 0$ value was 0.175 . Where the critical value of $\mathrm{LO}$ in the Liliefors table for sample size $(n)=40$ with $a=0.05$ obtained a value of 0.14 . When compared to the calculated LO value it turns out to be greater than the L0 table, so it can be concluded that the $\mathrm{X} 2$ normality test has an abnormal effect

\section{Normality Test X3}

Based on the calculation results of the liliefors normality test, the L0 value is 0.1261 . Where the critical L0 value in the liliefors table for the sample size $(n)=40$ with $\mathrm{a}=0.05$, a value of 0.14 is obtained. When compared to the calculated L0 value it turns out to be smaller than the L0 table, so it can be concluded that the X3 normality test has a normal effect

\section{Normality Test Y}

Based on the calculation results of the liliefors normality test, the L0 value of 0.0781 obtained where the

critical L0 value in the liliefors table for the sample size $(\mathrm{n})=40$ with $\mathrm{a}=0.05$ obtained a value of 0.14 . When compared to the calculated LO value it turns out to be smaller than the L0 table, so it can be concluded that the Y normality test has a normal effect.

\section{Test (X1) to (Y)}

Based on the results of the calculation of the regression linearity test obtained by the price $\mathrm{F}$ (regression linearity test) of 0.2606 . Where the $\mathrm{F}$ value is obtained value of 2.8742 . When compared to the value of Fcount it turns out to be smaller than Ftable, so it can be concluded that the linearity regression test $\mathrm{X} 1$ towards $\mathrm{Y}$ has a normal effect. While the regression significance test obtained $F$ price of 1.2638 . Where the $F$ value is obtained a value of 4.10 . When compared, the Fcount value turns out to be smaller than Ftable, so it can be concluded that the $\mathrm{X} 1$ regression significance test for $\mathrm{Y}$ has an abnormal effect.

\section{Test (X2) against (Y)}

Based on the results of the calculation of the regression linearity test obtained by the $\mathrm{F}$ price (regression linearity test) of 0.0077 . Where the $\mathrm{F}$ value is obtained value of 2.8742 . When compared to the value of Fcount it turns out to be smaller than Ftable, so it can be concluded that the regression linearity $\mathrm{X} 2$ test for $\mathrm{Y}$ has a normal effect. While the regression significance test obtained by the $\mathrm{F}$ price of 8.8829 . Where the $\mathrm{F}$ value is obtained a value of 4.10. When compared to the value of Fcount it turns out to be greater than Ftable, so it can be concluded that the $\mathrm{X} 2$ regression significance test for Y has a normal effect. 
Test (X3) against (Y)

Based on the results of the calculation of the regression linearity test obtained by the price $\mathrm{F}$ (regressionlinearity test) of 0.0766 . Where the $\mathrm{F}$ value is obtained value of 2.8742 . When compared to the value of Fcount it turns out to be smaller than Ftable, so it can be concluded that the linearity regression test $\mathrm{X} 3$ on $\mathrm{Y}$ has a normal effect. While the regression significance test obtained by an $\mathrm{F}$ price of 1.5312 . Where the $\mathrm{F}$ value is obtained a value of 4.10. When compared to the value of Fcount it turns out to be greater than Ftable, so it can be concluded that the $\mathrm{X} 3$ regression significance test for $\mathrm{Y}$ has an abnormal effect.

Test (X1) against (X3)

Based on the results of the calculation of the regression linearity test, the $\mathrm{F}$ value (regression linearity test) was 0.6702 . Where the $F$ value is obtained value of 2.8742 . When compared to the value of Fcount it turns out to be smaller than Ftable, so it can be concluded that the linearity regression test $\mathrm{X} 1$ against $\mathrm{X} 3$ has a normal effect. While the regression significance test obtained by the $\mathrm{F}$ price of -0.5280 . Where the $F$ value is obtained a value of 4.10. When compared to the value of Fcount it turns out to be smaller than Ftable, so it can be concluded that the $\mathrm{X} 1$ regression significance test for $\mathrm{X} 3$ has an abnormal effect.

Test (X2) against (X3)

Based on the results of the calculation of the regression linearity test, the $\mathrm{F}$ value (regression linearity test) was 1.0650 . Where the $\mathrm{F}$ value is obtained value of 2.8742 . When compared to the value of Fcount it turns out to be greater than Ftable, so it can be concluded that the linearity test of X1 to $\mathrm{X} 3$ has an abnormal effect. While the regression significance test obtained by the $\mathrm{F}$ value of -2.1773 . Where the $\mathrm{F}$ value is obtained a value of 4.10 . When compared to the Fcount value it turns out to be smaller than Ftable, so it can be concluded that the $\mathrm{X} 2$ regression significance test for $\mathrm{X} 3$ has an abnormal effect.

Direct Effect of Hand Eye Coordination (X1) on the Accuracy Ability of Shooting Petanque (Y) Athletes of Jambi Province.

Individual test conducted by hand-eye coordination (X1) on Shooting Petanque Accuracy Ability (Y) found that the path coefficient pyx1 $=0.299$ with tcount $=2.334$ and ttable $(1-0.05)$ $(39-1)=1.68($ at $\alpha=0.05)$. Because tcount $=$ $2.334>$ ttable $=1.68$, then Ho isrejected, meaning the path coefficient is significant. Thus Hand Eye Coordination (X1) directly and significantly influences the Accuracy of Shooting Petanque (Y).

The direct effect of Concentration (X2) on the Accuracy Capability of Shooting Petanque (Y) Athletes of Jambi Province.

Individual tests conducted concentrations (X2) on Shooting Petanque Accuracy (Y) found that the results of the path coefficient pyx $2=0.405$ with tcount $=2.482$ and ttable $(1-0.05)(39-1)=1.68$ (at $\alpha=0,05)$. Because tcount $=2.482>$ ttable $=1.68$, Ho is rejected, meaning the path coefficient is significant. Thus Concentration (X2) directly and significantly influence the Shooting Petanque (Y) Accuracy Ability.

Direct Effect of Confidence (X3) on the Accuracy Capability of Shooting Petanque (Y) Athletes of Jambi Province.

Confidence (X3) individual test of Shooting

Petanque Accuracy Ability (Y) found that the path coefficient pyx $3=0.288$ with tcount $=2.222$ and ttable $(1-0.05)(39-1)=1.68$ (at $\alpha=0.05)$. Because tcount $=2.221>\mathrm{t}$ table $=1.68$, Ho is rejected, meaning the path coefficient is significant. Thus Confidence (X3) has a direct and significant effect on the accuracy of Shooting Petanque (Y).

The indirect effect of hand eye coordination (X1) on the accuracy of shooting Petanque (Y) through Confidence (X3).

Individual tests conducted by hand eye coordination (X1) on the Accuracy of Shooting Petanque (Y) through confidence (X3) were obtained from the product of the pyx 3 path coefficient $=511$ with tcount $=3.829$, pyx31 $=0.861$ with tcount $=3.829$ and ttable $(1-0.05)(39-1)=1.68$ (at $\alpha=0.05$ ). Because tcount $=3.829>$ ttable $=1.68$, Ho is rejected, meaning the path coefficient is significant. Thus Hand Eye Coordination (X1) indirectly and significantly influences the Accuracy of Shooting Petanque (Y) Ability through confidence (X3).

Indirect Effect of Concentration (X2) on the Accuracy Ability of Shooting Petanque (Y) Through Confidence (X3).

Individual tests conducted concentrations (X2) of the Shooting Petanque Accuracy Ability (Y) through confidence (X3) were obtained from the product of the pyx 3 path coefficient value $=0.511$ with tcount $=2.622$, pyx32 $=0.232$ with tcount $=$ 2.414 and ttable (1-0), 05) (39-1) $=1.68$ (at $\alpha=$ 0.05 ). Because tcount $=2.414>$ ttable $=1.68$, Ho is rejected, meaning the path coefficient is significant. Thus Concentration (X2) has an indirect and significant effect on the accuracy of shooting Petanque (Y) through confidence (X3).

Tabel 1. Summary of Calculation Results for Path Coefficients

\begin{tabular}{|c|c|c|c|}
\hline Pathway & $\begin{array}{c}\text { Path } \\
\text { coefficient }\end{array}$ & tcount & ttable \\
\hline py1 & 0,299 & 2,344 & \\
\hline py2 & 0,405 & 2,482 & \\
\hline py3 & 0,288 & 2,221 & \\
\hline p31 & 0,861 & 3,829 & 1,68 \\
\hline p32 & 0,232 & 2,414 & \\
\hline
\end{tabular}




\section{IV.CONCLUSION}

Based on data analysis and statistical calculations outlined in the previous chapter of the discussion of the results of research conducted on Jambi provincial athletes, the following conclusions can be drawn: 1). There is a direct influence between hand eye coordination (X1) on shooting skills in petanque (Y) play in Jambi Province athletes. 2). There is a direct influence between concentration (X2) on shooting skills in petanque (Y) play in Jambi Province athletes. 3). There is a direct influence between self-confidence (X3) on shooting skills in petanque (Y) play in Jambi Province athletes. 4). There is an indirect influence of hand eye coordination (X1) through confidence (X3) on the shooting accuracy of Jambi Province athletes. 5). There is an indirect effect of concentration (X2) through confidence (X3) on the shooting accuracy of Jambi Province athletes.

\section{REFERENCES}

[1] Undang-Undang Republik Indonesia Nomor 3. Tahun 2005 Tentang "Sistem Keolahragaan Nasional". Kementerian Negara Pemudadan Olahraga Republik Indonesia. Jakarta . 2007. pp 23

[2] M. Sajoto. "Pembinaan Kondisi Fisik Dalam Olahraga". Jakarta, Departemen Pendidikan dan Kebudayaan. Direktur Jendral Pendidikan Tinggi. Proyek Pengembangan Lembaga Pendidikan Tenaga Kependidikan. 1988.pp 30

[3] Mudhalifa. "Hubungan Kekuatan Otot Lengan, Koordinasi Mata tangan Dan Keseimbangan Terhadap Ketepatan Shooting Olahraga Petanque Pada Atlet Klub Petanque Kediri 2017/2018”. Simki-Techsain Vol. 02 No. 04 pp. 2018

[4] NA, Samsudin. "The Effects Of Different Focus Of Attention On Throwing Skills Among Autistic Spectrum Disorder Children”. J FundamAppl Sci. 2017, 9(6S), pp. 1312-1322. Nov 2017

[5] Sukadiyanto. "Model Pembelajaran Kemampuan Koordinasi Pada Siswa Sekolah Dasar". Jurnal Pendidikan Jasmani Indonesia, Volume 3, No. 1, 2005

[6] Bompa. "Klasifikasi Latihan". Pustaka Indonesia. Jakarta. 2004. pp 45

[7] Badruzaman. "Hubungan Power Otot Lengan Dan Koordinasi Dengan Kecepatan Dan Ketepatan Smash Dalam Cabang Olahraga Bulutangkis". Jurnal Terapan Ilmu Keolahragaan 2017 Vol.02 No.01 pp 44-50 Jan 2010

[8] A. Mappaompo. "Koordinasi mata kaki, keseimbangan, kelincahan, dan keterampilan menggiring dalam sepak bola". Jurnal Penelitian Pendidikan INSANI, Volume 18, Nomor 1, pp. 11-16 June 2015

[9] Reza.H, Imanudin I, el. "Hubungan Power Otot Lengan Dan Koordinasi Dengan Kecepatan Dan Ketepatan Smash Dalam Cabang Olahraga Bulutangkis". Jurnal Terapan Ilmu Keolahragaan Vol.02 No.01 pp 44-50. Jan 2017

[10] Giriwijoyo, el." Ilmu faal olahraga." Edisi 8. Bandung: Universitas Pendidikan Indonesia. 2010.pp 15

[11] Tri Iswoyo, Dkk. "Sumbangan Keseimbangan, Koordinasi Mata Tangan Dan Power Lengan Terhadap Ketepatan Pukulan Boast Dalam Permainan Squash". Journal of Sport Sciences and Fitness 4.pp 23-33. Nov 2015

[12] Sri Handayani Dkk. "Pengaruh Aktivitas Kolase Terhadap Keterampilan Motorik Halus Pada Anak Usia Dini Melalui Metode Bermain Di Tk Pembina Kabupaten Rembang”. Jurnal Ilmu-Ilmu Sejarah, Sosial, Budaya dan Kependidikan, Vol 5 No 1, pp: 38-53. June 2018

[13] Sukadiyanto. "Keterampilan Grounstrokes Petenis Pemula". Jakarta : PPs. 2003.pp 45
[14] Komarudin. "Psikologi Olahraga". Bandung : PT Remaja Rosdakarya. 2013. pp 25.

[15] J. Miftakhul. "Kecemasan dan Konsentrasi Pada Atlet Panahan Anxiety and Concentration among Archery Athletes". Jurnal Psikologi Teoridan Terapan, Vol. 8, No. 1, pp. 53-60, August 2017

[16] N. Maemun. "Melatih Konsentrasi Dalam Olahraga". Vol 15 No 2,pp $54-61$. Juli 2016

[17] TjungHauw., Sin. "Tingkat Percaya Diri Atlet Sepak Bola dalam Menghadapi Pertandingan". Jurnal Fokus Konseling , ISSN 2356-2102 Volume 3, No. 2 pp,163-174. August 2017 